Original Article

\title{
ABSENCE OF NEPOTISM IN WAGGLE COMMUNICATION OF HONEYBEES (APIS MELLIFERA)
}

\author{
Zu Yun Zhang ${ }^{1,2}$ \\ Zhen $\mathrm{Li}^{1}$ \\ Qiang Huang ${ }^{1}$ \\ Wu Jun Jiang ${ }^{3}$ \\ Zhi Jiang Zeng ${ }^{1 *}$ \\ 'Honeybee Research Institute, Jiangxi Agricultural University, Nanchang, Jiangxi, \\ 330045, P. R. of China \\ 2Sericultural and Apicultural Institute, Yunnan Academy of Agricultural Sciences, \\ Mengzi, Yunnan, 661101, P. R. of China \\ ${ }^{3}$ Apicultural Institute of Jiangxi Province, Nanchang, Jiangxi, 330052, P. R. of China \\ *corresponding author: bees1965@sina.com \\ Received: 24 February 2020; accepted: 13 July 2020
}

Abstract

The polyandrous mating behavior of the honeybee queen increases the genetic variability among her worker offspring and the workers of particular subfamilies tend to have a genetic predisposition for tasks preference. In this study, we intended to understand whether there is nepotism in dance communication of honeybees during natural conditions. Microsatellite DNA analyses revealed a total of fourteen and twelve subfamilies in two colonies. The subfamily composition of the dancer and the followers did not deviate from random. The majority of the subfamilies did not show kin recognition in dancerecruit communication in honeybee colonies, but some subfamilies showed significant nepotism for workers to follow their super-sister dancer. Because it seems unlikely that honeybee would change the tendency to follow dancers due to the degree of relatedness, we conclude that honeybees randomly follow a dancer in order to e benefit colony gain and development.

Keywords: microsatellite DNA, nepotism, recruits, subfamily, waggle dance

\section{INTRODUCTION}

Honeybees are a model organism to study the genetic basis of task specialization in social insects due to the polyandrous queen (Robinson et al., 2005). Generally, from six to twenty subfamilies (paternity) co-exit within a honeybee colony that are genetically different, and these genetic differences have also translated into different behavior preference (Page \& Robinson, 1991). Genetic variability has been described for such behavioral traits as nectar and pollen foraging (Page \& Robinson, 1991), nest site scouting(Robinson\& Page, 1989), plantchoice for pollen collection (Oldroyd et al., 1992), foraging distance (Oldroyd et al., 1993), water collecting and scenting (Кryger et al., 2000), fanning (Su et al., 2007), emergency queen-cell building (Xie et al., 2008), mite (Varroa destructor) parasitism rate (Liu et al., 2009), swarming (Huang \& Zeng, 2009), survival differences (Wang et al., 2012) and feeding preference (Yi et al., 2018).

Honeybees have evolved numerous mechanisms to increase colony-level foraging efficiency, mainly the combined system of scout-recruit division of labor and recruitment communication (von Frisch, 1967; Seeley, 1998). This recruitment process incorporates information about the food reward, the colony food stores and the environmental food availability (George \& Brockmann, 2019). At the individual level, the efficiency of a scout depends on its ability to find and inform the nest mates of the food source. $A$ successful forager performs waggle dances on the surface of the comb where it interacts with nectar receivers and dance followers (Seeley, 
1998). The responses to the waggle dance signal reflect the contextual information possessed by various honeybees on the dance floor (Seeley \& Towne, 1992). Honeybee workers might be able to behave nepotistically and favor the reproductive success of their subfamily (Getz et al., 1983; Page et al., 1989, 1990).

Oldroyd (1991) showed that a strong tendency for recruits to follow their super-sister dancers. This may increase honeybee colony efficiency in dance communication. Arnold (2002) suggested that sub-familial variance for propensity may vary both for waggle and tremble dances. However, neither in a colony consisting of only two subfamilies nor in a colony consisting of seventeen subfamilies was there any evidence of subfamily discrimination among dancers and their followers foraging from artificial feeding site that provided sucrose solution (Kirchner \& Arnold, 2001). However, the result might be biased by the subfamilies' preferences of nectar and pollen foraging (Page \& Robinson, 1991). In order to avoid the foraging preference, we used colonies during natural foraging rather than using an artificial feeder. The aim of the present study is to determine any nepotism in dancing recruitment under natural conditions. We therefore determined the subfamily frequencies of natural mated colonies, as well as the subfamily of the dancers and followers through microsatellite genetic markers.

\section{MATERIAL AND METHODS}

\section{Samples Collection}

The experiments were conducted with two honeybee colonies (colony $A$ and colony B) with naturally mated queens during natural foraging from food resources rather than a artificial feeding site providing sucrose solution. Each colony was composed of four frames of honeybees and housed in observation hives. One side of the observation hives was open during the experiments to pick honeybees from the combs for genetically analysis. The dancing floor area of the observation hive was observed. The foragers which had been observed ten times in a row to perform a waggle dance after returning from the food source were classified as waggle dancers. The dancing followers were defined as the honeybees attending a waggle dance persistently for several circuits. When the foragers were dancing, the recruits followed her to dance, forming a circle. The outer followers were captured first in a box and the center dancer was captured later in an EP tube. A dancer and dance followers were defined as a group (on average eight followers per dancer). The dancer and dance followers were immediately frozen on dry ice and kept for later determination of their subfamily membership. Thirteen groups of honey bees were collected from colony A, including thirteen dancers and 117 followers. Twelve groups of honey bees were collected from colony $B$, including twelve dancers and ninety-three followers. For each dancer, a minimal of five followers was collected. Additionally, sixty-four (colony A) and forty-eight (colony B) workers were randomly picked out to represent the overall subfamily composition of the colonies.

\section{DNA Amplification and Genetic Analysis}

After the sampling, a genomic DNA extraction kit (StarSpin Animal DNA Kit) was used to extract DNA of each sample individually. Three microsatellite loci (A14, A24 and A113) were selected to determine the subfamilies according to previous reports (Tian et al., 2013; Zhang et al., 2017; Yi et al., 2018) (Tab. 1). These sequences have a high degree of polymorphism. The PCR reaction mixture $(25 \mathrm{~L})$ was as follows: $1 \mu \mathrm{L}$ of DNA (100 $\mathrm{ng} / \mu \mathrm{L}), 1 \mu \mathrm{L}$ each of forward and reverse primer $(10 \mu \mathrm{M}), 12.5 \mu \mathrm{L}$ of SinoBio 2×Master Mix (Taq DNA Polymerase, dNTP, $\mathrm{Mg}^{2+}$, reaction buffer, Vazyme Biotech CO., Ltd) and $9.5 \mu \mathrm{L}$ of ultrapure sterile water $\left(\mathrm{ddH}_{2} \mathrm{O}\right)$. The loci were amplified using Bio-RAD T100 ${ }^{\mathrm{TM}}$ thermal cyclers through thirty cycles consisting of denaturation for $30 \mathrm{~s}$ at $94^{\circ} \mathrm{C}$, annealing for $45 \mathrm{~s}$ at $55-60^{\circ} \mathrm{C}$ (depending on the locus) and elongation for $60 \mathrm{~s}$ at $72^{\circ} \mathrm{C}$ (Tab. 1). The allele of each microsatellite marker was determined with capillary electrophoresis (QIAxcel Advanced system). Then, the subfamily was analyzed using Mate-soft (Moilanen, et al., 2004). 
Table 1.

Description of primer sequences and reaction condition used for microsatellites

\begin{tabular}{|c|c|c|c|c|}
\hline Locus & Sequence of primers & Allele size (bp) & $\begin{array}{c}\text { Annealing } \\
\text { temperature } \\
\left({ }^{\circ} \mathrm{C}\right)\end{array}$ & $\begin{array}{l}\text { No. } \\
\text { cycles }\end{array}$ \\
\hline A14 & $\begin{array}{l}\text { F5'-GTGTCGCAATCGACGTAACC-3' } \\
\text { R 5'-GTCGATTACCGATCGTCACG-3' }\end{array}$ & 215/220/225/235245 & 58 & 30 \\
\hline$A 24$ & $\begin{array}{l}\text { F5'-CACAAGTTCCAACAATGC-3' } \\
\text { R 5'-CACATTGAGGATGAGCG-3' }\end{array}$ & $110 / 120$ & 55 & 30 \\
\hline A113 & $\begin{array}{c}\text { F5'-CTCGAATCGTGGCGTCC-3' } \\
\text { R 5'-CCTGTATTTTGCAACCT CGC-3' }\end{array}$ & 210/215/225/235 & 60 & 30 \\
\hline
\end{tabular}

\section{Statistic Analysis}

All statistic analysis was conducted using SPSS Statistics 26.0. The distribution of workers in each subfamily between dancing followers and randomly collected workers was analyzed using Fisher's exact test. The distribution of recruits in all super-sister of against all other half-sisters was analyzed using Fisher's exact test (Кryger et al., 2000).

\section{RESULTS}

Genotypes of paternity were calculated in each colony respectively (Tab. 2). As the subfamily frequencies were unequal in our samples, we extended the statistical analysis by considering the subfamilies separately. Colony A consisted of fourteen subfamilies, and twenty-two of

Table 2.

Genotypes of paternity were in each colony

\begin{tabular}{cccccc}
\hline \multicolumn{7}{c}{ Colony A } & & \multicolumn{3}{c}{ Colony B } \\
\hline Subfamilies & $\begin{array}{c}\text { Genotypes of } \\
\text { paternity } \\
\text { A014/A024/A113 }\end{array}$ & $\begin{array}{c}\text { Random } \\
\text { samples }\end{array}$ & Subfamilies & $\begin{array}{c}\text { Genotypes of } \\
\text { paternity } \\
\text { A014/A024/A113 }\end{array}$ & $\begin{array}{c}\text { Random } \\
\text { samples }\end{array}$ \\
\hline 1 & $225 / 120 / 215$ & 18 & 1 & $215 / 120 / 215$ & 6 \\
2 & $225 / 120 / 235$ & 12 & 2 & $215 / 120 / 210$ & 4 \\
3 & $225 / 120 / 225$ & 9 & 3 & $235 / 120 / 215$ & 8 \\
4 & $215 / 120 / 235$ & 8 & 4 & $220 / 120 / 215$ & 7 \\
5 & $215 / 120 / 215$ & 6 & 5 & $225 / 120 / 215$ & 5 \\
6 & $215 / 120 / 225$ & 2 & 6 & $215 / 120 / 235$ & 5 \\
7 & $245 / 120 / 215$ & 2 & 7 & $235 / 110 / 225$ & 5 \\
8 & $235 / 120 / 225$ & 2 & 8 & $235 / 120 / 235$ & 3 \\
9 & $225 / 110 / 215$ & 1 & 9 & $245 / 120 / 215$ & 0 \\
10 & $235 / 120 / 235$ & 2 & 10 & $235 / 120 / 210$ & 1 \\
11 & $245 / 110 / 225$ & 0 & 11 & $220 / 120 / 235$ & 3 \\
12 & $245 / 120 / 235$ & 2 & 12 & $220 / 120 / 210$ & 1 \\
13 & $235 / 110 / 235$ & 0 & & & \\
14 & $235 / 110 / 215$ & 0 & & & \\
\hline
\end{tabular}

Note: Colony A consisted of 14 paternity, colony B of 12 . 
Table 3.

Distribution of super-sisters and half-sisters in colony $A$

\begin{tabular}{ccccccc}
\hline \multicolumn{2}{c}{ Dancer } & \multicolumn{5}{c}{ Recruits } \\
\hline No. & Subfamilies & $\begin{array}{c}\text { Super-sister } \\
\text { Observed }\end{array}$ & $\begin{array}{c}\text { Half-sisters } \\
\text { Observed }\end{array}$ & $\begin{array}{c}\text { Super-sister } \\
\text { Expected }\end{array}$ & $\begin{array}{c}\text { Half-sisters } \\
\text { Expected }\end{array}$ & $\begin{array}{c}\text { P } \\
\text { values }\end{array}$ \\
\hline A1 & 5 & 1 & 11 & 1.1 & 10.9 & 1.000 \\
A2 & 7 & 0 & 11 & 0.3 & 10.7 & 1.000 \\
A3 & 7 & 1 & 8 & 0.3 & 8.7 & 1.000 \\
A4 & 6 & 0 & 8 & 0.2 & 7.8 & 1.000 \\
A5 & 3 & 3 & 4 & 1.0 & 6.0 & 0.559 \\
A6 & 1 & 1 & 6 & 2.0 & 5.0 & 1.000 \\
A7 & 2 & 2 & 4 & 1.1 & 4.9 & 1.000 \\
A8 & 1 & 3 & 6 & 2.5 & 6.5 & 1.000 \\
A9 & 6 & 5 & 2 & 0.2 & 6.8 & 0.021 \\
A10 & 10 & 1 & 6 & 0.2 & 6.8 & 1.000 \\
A11 & 3 & 1 & 10 & 1.6 & 9.4 & 1.000 \\
A12 & 6 & 1 & 12 & 0.4 & 12.6 & 1.000 \\
A13 & 5 & 3 & 7 & 0.9 & 9.1 & 0.582 \\
\hline
\end{tabular}

Note: The last column gives the P- values for Fisher exact tests for the distribution of the number of supersister against all other half-sisters in each group. Fisher's exact test (two-tailed) for the distribution of the number of super-sister against all other half-sisters on the whole $\left(\chi^{2}=3.760, \mathrm{df}=6, \mathrm{P}=0.768\right)$.

Distribution of super-sisters and half-sisters in colony B

Table 4.

\begin{tabular}{ccccccc}
\hline \multicolumn{2}{c}{ Dancer } & \multicolumn{5}{c}{ Recruits } \\
\hline No. & Subfamilies & $\begin{array}{c}\text { Super-sister } \\
\text { Observed }\end{array}$ & $\begin{array}{c}\text { Half-sisters } \\
\text { Observed }\end{array}$ & $\begin{array}{c}\text { Super-sister } \\
\text { Expected }\end{array}$ & $\begin{array}{c}\text { Half-sisters } \\
\text { Expected }\end{array}$ & P values \\
\hline B1 & 1 & 1 & 6 & 0.9 & 6.1 & 1.000 \\
B2 & 4 & 1 & 7 & 1.2 & 6.8 & 1.000 \\
B3 & 1 & 2 & 7 & 1.1 & 7.9 & 1.000 \\
B4 & 6 & 0 & 8 & 0.8 & 7.2 & 1.000 \\
B5 & 1 & 4 & 1 & 0.6 & 4.4 & 0.206 \\
B6 & 2 & 1 & 6 & 0.6 & 6.4 & 1.000 \\
B7 & 9 & 1 & 6 & 0 & 7.0 & 1.000 \\
B8 & 5 & 2 & 5 & 0.7 & 6.3 & 1.000 \\
B9 & 3 & 1 & 8 & 1.5 & 7.5 & 1.000 \\
B10 & 1 & 6 & 4 & 1.3 & 8.7 & 0.057 \\
B11 & 1 & 3 & 4 & 0.9 & 6.1 & 0.559 \\
B12 & 8 & 1 & 8 & 0.6 & 8.4 & 1.000 \\
\hline
\end{tabular}

Note: The last column gives the P- values for Fisher exact tests for the distribution of the number of supersister against all other half-sisters in each group. Fisher's exact test (two-tailed) for the distribution of the number of super-sister against all other half-sisters on the whole $\left(\chi^{2}=5.516, \mathrm{df}=7, \mathrm{P}=0.498\right)$. 


\section{Ј. APPC. SOLI. VOL. 64 N NO. 2 2020}

117 dance followers were super-sisters of the dancers and ninety-five were half-sisters (Tab. $2,3)$. Colony B consisted of twelve subfamilies, where twenty-three of ninety-three analyzed followers were super-sisters of the dancers and seventy were half-sisters (Tab. 2, 4). In colony A, a single group showed significant nepotism for workers to follow super-sister dancer (chisquare test: $\chi^{2}=7.778, d f=1, P=0.021$ ). However, significant preference to nepotism was not observed between the distribution of the waggle dancers and that of the dance followers overall in colony $A$ (chi-square test: $c^{2}$ $=3.760, d f=6, P=0.768$ ) (Tab. 3). For colony $B$, neither individual group nor whole colony showed a significant preference to nepotism between the waggle dancers and that of the dance followers on the whole (chi-square test: $c^{2}=5.516, d f=7, P=0.498$ ) (Tab. 4).

\section{DISCUSSION}

For our study, the data show that there was no subfamily nepotism among dancers and their followers. Oldroyd (1991) reported that honeybees dance preferentially with their super-sisters, which suggests a strong tendency to recruit super-sisters and indicates subfamily discrimination. The tendency of a recruit to follow a dancer was affected by the subfamily of the recruit, the subfamily of the dancer, foraging preferences of dancer and what she was carrying (Waddington, 1989; Page \& Robinson, 1991). Here we show that recognition between super-sisters and half-sisters is at least not a general feature of the dance communication system.

Honeybees are eusocial insects, specialized in information sharing, division and cooperation. Even though the location and quality of the food resource, as well as the season shapes the foraging behavior, any significant impacts on nepotism have not been identified (Oldroyd et al., 1992, 1993, 1994). Kirchner and Arnold (2001) found no evidence for subfamily discrimination among dancers and their followers in a colony. However, honeybees just foraged from an artificial feeding site providing sucrose solution. So, the result might be due to different foraging preferences of the subfamilies. Gilley (2014) also suggest that the waggle-dance hydrocarbons play an important role in honeybee foraging recruitment by stimulating foragers to perform waggle dances. In addition, dance activity for food sources was regulated by an inter-play between individual response thresholds and the social context obtained through interaction with nest mates (George \& Brockmann, 2019). Thus, honeybee would unlikely change the tendency to follow dancers due to the degree of relatedness. The single significant nepotism group found in our data might be due to the difficulty of sampling and the low number of followers in that group. This helps the colony to efficiently utilize its foraging force to effectively exploit food sources in its environment. Thus, we conclude that honeybees do not show kin recognition in dance-recruit associations under natural conditions.

\section{ACKNOWLEDGEMENTS}

This work was supported by the National Natural Science Foundation of China (31572469, 31872432), the Earmarked Fund for China Agriculture Research System (CARS-44-KXJ15).

\section{REFERENCES}

Arnold, G., Quenet, B., Papin, C., Masson, C., Kirchner, W.H. (2002). Intra-colonial variability in the dance communication in honeybees (Apis mellifera). Ethology, 108(9), 751-761. DOl: 10.1046/j.14390310.2002.00809.x

George, E.A., \& Brockmann, A. (2019). Social modulation of individual differences in dance communication in honey bees. Behavioral Ecology and Sociobiology, 73(4), 41-55. DOl: 10.1007/ s00265-019-2649-0

Getz, W.M., \& Smith, K.B. (1983). Genetic kin recognition: honey bees discriminate between full and half sisters. Nature, 302, 147-148. DOl: 10.1038/302147a0 
Gilley, D.C. (2014). Hydrocarbons emitted by waggledancing honey bees increase forager recruitment by stimulating dancing. PLOS ONE, 9, e105671. DOl:10.1371/journal.pone.0105671

Huang, Q., \& Zeng, Z.J. (2009). Nepotism in swarming honeybees (Apis cerana cerana). Chinese Bulletin of Entomology, 46, 107-111.

Kirchner, W.H., \& Arnold, G. (2001). Intracolonial kin discrimination in honeybees: do bees dance with their supersisters? Animal Behaviour, 67(3), 597600. DOl: 10.1006/anbe.2000.1626

Kryger, P., Kryger, U., \& Moritz, R.F.A. (2000). Genotypical variability for the tasks of water collecting and scenting in a honey bee colony. Ethology, 106(9), 769-779. DOl: 10.1046/j.14390310.2000.00571.x

Liu, Y.B., Huang, Q., \& Zeng, Z.J. (2009). Study on the selective parasitism of the varroa mite to the different subfamilies by ISSR. Journal of Bee, 8, 6-9.

Moilanen, A., Sundstroem, L., \& Pedersen, J.S. (2004). Matesoft: a program for deducing parental genotypes and estimating mating system statistics in haplodiploid species. Molecular Ecology Notes, 4, 795-797. DOl: 10.1111/j.1471-8286.2004.00779.x

Oldroyd, B.P., Rinderer, T.E., \& Buco, S.M. (1991). Honey bees dance with their super sisters. Animal Behaviour, 42(1), 121-129. DOl: 10.1016/s00033472(05)80612-8

Oldroyd, B.P., Rinderer, T.E., \& Buco S.M. (1992). Intracolonial foraging specialism by honey bees (Apis mellifera) (Hymenoptera: Apidae). Behavioral Ecology and Sociobiology, 30, 291-295. DOl: 10.1007/ BF00170594

Oldroyd, B.P., Rinderer, T.E., Buco S.M., \& Beaman, L. (1993). Genetic variance in honeybees for preferred foraging distance. Animal Behaviour, 45(2), 323332. DOl: 10.1006/anbe.1993.1037

Oldroyd, B.P., Rinderer, T.E. Schwenke, J.R., \& Buco, S.M. (1994). Subfamily recognition and task specialization in honey bees (Apis mellifera) (Hymenoptera: Apidae). Behavioral Ecology and Sociobiology, 34, 169-173. DOl: 10.1007/BF00167741

Page, R.E., Robinson, G.E., \& Fondrk, M.K. (1989). Genetic specialist, kin recognition and nepotism in honeybee colonies. Nature, 338, 576-579. DOl: 10.1038/338576a0

Page, R.E., Breed, M.D., \& Getz, W. (1990). Nepotism in the honey bee. Nature, 346, 707. DOl: $10.1038 / 346707 a 0$

Page, R.E., \& Robinson, G.E. (1991). The genetics of division of labor in honey bee colonies. Advances in Insect Physiology, 23(C), 117-169. DOl: 10.1016/ S0065-2806(08)60093-4

Raymond, M., \& Rousset, F. (1995). An exact test for population differentiation. Evolution, 49(6), 12801283. DOl: 10.2307/2410454

Robinson, G.E., \& Page, R.E. (1989). Genetic determination of nectar foraging, pollen foraging, and nest-site scouting in honey bee colonies. Behavioral Ecology and Sociobiology, 24, 317-323. DOl: 10.1007/BF00290908

Robinson, G.E., Grozinger C.M., \& Whitfield, C.W. (2005). Socio-genomics: social life in molecular terms. Nature Reviews Genetics, 6, 257-270. DOl:10.1038/пrg1575

Seeley, T.D., \& Towne, W.F. (1992). Tactics of dance choice in honey bees: do foragers compare dances? Behavioral Ecology and Sociobiology, 30, 59-69. D0l: 10.1007/BF00168595

Seeley, T.D. (1998). Thoughts on information and integration in honey bee colonies. Apidologie, 2912), 67-80.

Su, S.K., Alber, T.S., Zhang, S., Maier, S., Chen, S.L, Du, H., Tauzt, I. (2007). Non-destructive genotyping and genetic variation of fanning in a honeybee colony. Journal of Insect Physiology, 53(5), 411-417. DOl: 10.1016/j.jinsphys.2007.01.002 
Tian L.Q., He, X.J., Wang, H., \& Zeng, Z.J. (2013). Analysis of genetic background between two types of nurses in honeybee (Apis mellifera). Journal of Bee, 10, 1-3.

Von Frisch, K. (1967). The Dance language and orientation of bees. Cambridge, Massachusetts: Harvard University Press.

Wang, H., Zhang, S.W., Zhang, F., \& Zeng, Z.J. (2012). Analysis of life-spans of workers from different sub-families in a honeybee colony. Entomological Knowledge, 49, 1172-1175.

Waddington, K.D. (1989). Implications of variation in worker body size for the honey bee recruitment system. Journal of Insect Behavior, 2, 91-103. D0l: 10.1007/BF01053620
Xie, X.B., Sun, L.X., Huang, K., \& Zeng, Z.J. (2008). Worker nepotism during emergency queen rearing in Chinese honeybees Apis cerana cerana. Acta Zoologica Sinica, 54, 695-700.

Yi, Y., Yan, W.Y., Li, Y., Guo, Y.H., Zhang, L.Z., Zeng, Z.j., (2018). Genotypic variability of the queen retinue workers in honeybee colonies (Apis mellifera). African Entomology, 26(1), 30-35. DOl: 10.4001/003.026.0030

Zhang, Z.Y., Yang, R.P., Chen, L., YU, Y.S., Song, W.F." Wang, Y.H., Zhang, X.W. (2017). Genetic diversity analysis of mite-resistance honeybees (Apis mellifera) based on microsatellite markers. Journal of Southwest China Normal University, 42, 31-37. DOl: 10.13718/j.cnki.xsxb.2017.04.006 